Intersections

Canadian Journal of Music

Revue canadienne de musique
Intersections

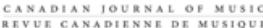

\title{
Fragments from a Broken Country: Jérôme Blais, in Discussion with Philipp Reisner
}

\section{Philipp Reisner}

Volume 38, numéro 1-2, 2018

URI : https://id.erudit.org/iderudit/1071678ar

DOI : https://doi.org/10.7202/1071678ar

Aller au sommaire du numéro

Éditeur(s)

Canadian University Music Society / Société de musique des universités

canadiennes

ISSN

1911-0146 (imprimé)

1918-512X (numérique)

Découvrir la revue

Citer ce document

Reisner, P. (2018). Fragments from a Broken Country: Jérôme Blais, in

Discussion with Philipp Reisner. Intersections, 38(1-2), 153-162.

https://doi.org/10.7202/1071678ar

Copyright @ Canadian University Music Society / Société de musique des universités canadiennes, 2020
Ce document est protégé par la loi sur le droit d'auteur. L'utilisation des services d'Érudit (y compris la reproduction) est assujettie à sa politique d'utilisation que vous pouvez consulter en ligne.

https://apropos.erudit.org/fr/usagers/politique-dutilisation/ 


\section{FRAGMENTS FROM A BROKEN COUNTRY: JÉRÔME BLAIS, IN DISCUSSION WITH PHILIPP REISNER}

\section{INTRODUCTION}

Composer Jérôme Blais, professor at Dalhousie University since 2004, has established himself as a major creative voice in Canada. In January 2019 his multimedia show mouvance, which he developed with soprano Suzie LeBlanc and several interdisciplinary collaborators, was premiered in Halifax, then repeated in February during the festival Montréal Nouvelles Musiques, presented by the Société de musique contemporaine du Québec.

His music, which encourages performers' creativity and exploits the intimate relationship between the musicians and their instruments, favours introspection and sound exploration. His style is characterized by a unique blend of multiple influences, from folk and popular to contemporary concert music.

After completing a bachelor's degree in music theory at McGill University, in 1995 Jérôme Blais obtained a master's degree in compositional techniques at l'Université de Montréal, where he completed his doctoral studies with Michel Longtin and Reno De Stefano in 2004. His research dealt with the integration of improvisation into the compositional process.

Jérôme Blais's works have been performed by several professional ensembles, among which are Norman Adams (Halifax), Array Music (Toronto), Bozzini String Quartet (Montreal), Bradyworks (Montreal), Continuum (Toronto), Simon Docking (Halifax), Ensemble contemporain de Montréal, D’Arcy Gray (Halifax), Wallace Halladay (Toronto), Corey Hamm (Vancouver), Janice Jackson (Halifax), Hank Knox (Montreal), Ang Li, Suzie LeBlanc (Montreal, Halifax), Mindful Flower Gamelan (Wolfville), Motion Ensemble (Sackville, New Brunswick), Musica Nova (Lennoxville), Orchestre Métropolitain de Montréal, Barbara Pritchard (Halifax), Quasar Saxophone Quartet (Montreal), Jeff Reilly (Halifax), Rosa Ensemble (Amsterdam), Société de musique contemporaine du Québec (Montreal), Symphony Nova Scotia (Halifax), Marcia Swanston (Halifax), Ziya Tabassian (Montreal), Toca Loca (Toronto), and Upstream Music Association (Halifax).

Recent prestigious performances of his works include in 2018 the performance of his work Soliloque 04 by Canadian and Italian cellists Norman Adams and Nicola Baroni at the Venice Biennale in October, the premieres of In D by violinist Mark Fewer, pianist Walter Delahunt, and cellist Adrian Brendel 
in November, and Licks by the Dalhousie Symphony Orchestra in December. In May 2016 his arrangement of the Yiddish song "Dremlen Feygl Oyf Di Tsvaygn" for chamber ensemble, by soprano Suzie LeBlanc with the Société de musique contemporaine du Québec in Montreal. The orchestral version of this arrangement, which is part of his song cycle Songs for Milena (dedicated to the memory of Czech journalist Milena Jesenská [1896-1944]), was performed by Janice Jackson and Yannick Nézet-Séguin's Orchestre Métropolitain de Montréal, conducted by Airat Ichmouratov. The complete song cycle was premiered by Janice Jackson and Symphony Nova Scotia conducted by Bernhard Gueller in January 2015. Other prestigious performances include his work Es ist genug!, which has been performed by Canadian pianist Ang Li over the last few years at several locations in Canada, in the United States, including at Carnegie Hall in New York City, as well as in Asia.

He has been invited as featured composer by festivals such as Newfound Music in St. John's, Newfoundland, Shattering the Silence in Wolfville, Nova Scotia, and Ok.Quoi?! in Sackville, New Brunswick. He also performs as a pianist and improviser, notably with saxophonist Jean-Marc Bouchard.

A recipient of a 2017 Creative Nova Scotia Established Artist Recognition Award, Blais is also an active music researcher and regularly presents the results of his research in conferences. In January 2016 he presented a conference paper as part of a colloquium on the work of composer John Rea at McGill University in Montreal. In 2010 he was invited as a keynote speaker by the Canadian University Music Society for its annual conference in Regina, Saskatchewan. His presentation for this event was published by the society's journal Intersections. ${ }^{1}$ In 2011 he participated in the Journée d'étude en improvisation at the University of Montreal. In 2008 he contributed a chapter on Canadian composer John Rea. ${ }^{2}$ His work on musical notation is the subject of a chapter in Composer au XXIe siècle: Pratiques, philosophies, langages et analyses (Paris: Vrin, 2011).

His research and compositional activities have received funding from such agencies as the Social Sciences and Humanities Research Council of Canada, the Fonds pour la formation de chercheurs et l'aide à la recherche (FCAR, now FQRSC), the Conseil des arts et des lettres du Québec (Quebec's Arts Council), the Canada Council for the Arts and the Nova Scotia Department of Tourism, Culture and Heritage, Culture Division.

His work mouvance, an eight-minute piece for soprano and bass clarinet based on a text by Acadian poet Gérald Leblanc, and Rafales, for solo oboe, were nominated for ECMA's Best Classical Composition of the Year in 2013 and 2014. Mouvance is included on the 2013 East Coast Music Association (ECMA) Award-winning Best Classical Recording Between the Shore and the Ships.

In 2016 Blais invited soprano Suzie LeBlanc to collaborate with him on the development of a complete multimedia show that would use his piece

\footnotetext{
1 “3 Improvisations," Intersections 31 (2): 99-112.

2 "Music under the Influence: On la nécessité extérieure in the Music of John Rea," in Compositional Crossroads: Music, McGill, Montreal, ed. Eleanor Stubley, 264-30o (Montreal and Kingston: McGill-Queen's University Press, 2008).
} 
mouvance as a starting point and that would offer a reflection on important Acadian themes such as distance, exile, and statelessness. In 2017 they received a New Chapter grant from the Canada Council for the Arts for this project, and Blais started to write new songs on texts by other prominent Acadian poets Sarah Marylou Brideau, Herménégilde Chiasson, France Daigle, Léonard Forest, Céleste Godin, Georgette LeBlanc, Gabriel Robichaud, Roméo Savoie, and Serge Patrice Thibodeau. Finally, they invited other artists to join their team of interdisciplinary collaborators: filmmaker Phil Comeau, stage director François Racine, and visual artist Karen Trask. Together, they created the unique immersive experience that is mouvance.

\section{CONVERSATION With THE COMPOSER}

Prompted by Jérôme's composition Fragments from a Broken Country. For Mezzo-soprano and Piano (2006-7) based on the poet Suji Kwock Kim's cycle Notes from the Divided Country (Baton Rouge, LA: Louisiana State University Press, 2003) - one of two contemporary compositions inspired by this collection of poetry-Jérôme and I started a conversation that turned into a fruitful exchange on central questions of contemporary aesthetics, be they literary or musical.

Philipp: Jérôme, you have recently finished mouvance, a production by Le Nouvel Opéra, presented by Montréal Nouvelles Musiques, which had its world premiere on 23 February 2019 at the Studio Théâtre Alfred Laliberté at the Université du Québec à Montréal. It is a multimedia chamber music piece for cello, guitar, clarinet, and percussion, featuring soprano Suzie LeBlanc and based on the work of Acadian poets Roméo Savoie and Gérald Leblanc.

Musical composition in the twentieth century has been characterized by a compositional turn towards the increasing use of percussion. You are using percussion in this piece in an intricate interplay with the human voice, and you had similarly used percussive elements of the piano by placing two Tibetan prayer bowls on the low strings of the prepared piano in Fragments from a Broken Country (2006-7). Can you describe what inspired your particular combination of percussion and the human voice, and how this relates to your enthusiasm for the poetry you set to music?

Jérôme: I can certainly identify several reasons for the prominence of percussion in my work. First, it is true that percussion has gained importance during the twentieth century and I am no different from most of my contemporaries in my enthusiasm for this group of instruments. For me, the main advantage of percussion instruments is the infinity of colours it gives me. With those instruments, I can create endless soundscapes that will fit any mood suggested by the poetry I am setting to music. With only one skilled player and a set-up that does not have to be huge, I have access to a variety of sound colours that may suggest a much larger ensemble, or that may also even suggest electroacoustic manipulations, even if the music is 100 per cent acoustic.

This is actually how I got to use the interior of the piano more and more in my music. Piano is my main instrument, but at some point I got frustrated 
with its tonal and timbral fixity. I became jealous of those playing strings or wind instruments and having the possibility to bend notes, modify their sound, etc. For "Fragments ...," more particularly, I was interested in created sounds that would be vaguely reminiscent of traditional Korean music that I love. I did not want to create anything that would make too direct a reference to this music; I just wanted to create an atmosphere that would be somewhat unreal but that would allude, in a dreamlike manner, to traditional Korea, a little bit like a lost paradise.

For mouvance I certainly had many reasons to use percussions. First, I wanted the instrumentation for this project to be reduced: first for personal taste, because I like to write light and transparent textures where I feel I can hear every sound; but also for practical reasons, because of limited budget and for the possibility to tour the piece in various places. As I mentioned above, percussion is an important component of a modern chamber ensemble, as it gives me access to an extremely wide colour palette.

In addition to this, I must say that in mouvance I make quite a bit of reference to popular music. At some points, I simply want to treat the ensemble a little bit like a "rhythm section" to accompany the voice. Therefore, I ask D'Arcy, the amazing percussionist who plays in the ensemble, to use his set-up in the way of a drum kit. I find the result quite fascinating because D'Arcy is a very capable improviser who understands popular music idioms, but he is not himself a traditional drum-kit player, and his set-up is not a traditional drum kit. The result is, for me, a unique hybrid between classical percussion set-up and drum kit. I call it my "colourful drum kit."

Finally, the instrumentation for mouvance is partly justified simply by the people who play the instruments, not just by the instruments themselves. This is particularly true for D'Arcy, a very precious collaborator with whom I've been working for years, as well as for Norman Adams, the cellist.

Philipp: You have mentioned the traditional Korean music you love and that was part of your inspiration for Fragments from a Broken Country. Could you share what specific traditions in Korean music you are thinking of?

Jérôme: I must confess I would not be able to identify a specific tradition. I am by no means an ethnomusicologist, and certainly not a specialist of Korean music. But I did consult a number of sources for inspiration. In particular, there were a couple of CDs that I enjoyed very much. One was a historic field recording made by John Levy for a label named Lyricord, a label that seems very much in line with the wonderful Folkways Records label. There was also a CD entitled Traditional Music from Korea, on the label ARC, a small UK label that looks interesting, and a CD by the Kim Suk Chul Ensemble.

Philipp: Your preference for percussion as you have described it makes one think of the narrative song genre sometimes misleadingly called Korean solo opera (P'ansori), the muted piano strings and glissandi of traditional Korean (long) board zither instruments such as the Gayageum and Geomungo ...

Jérôme: Interesting .... I must confess I did not really know of this. My use of those special techniques with the piano was certainly to create a sound world that would somehow recall Korean music, but I did it intuitively. I must confess 
that nowadays, with important discussions going on in Canada on cultural appropriation, I'm not sure I would still dare approach a project in the same way. I am not sure how big a topic this is elsewhere in the world, but in Canada right now, it can certainly yield heated debate ....

Philipp: Korean traditional music is sometimes seen as expressing an optimistic spirit that transforms sorrow and despair into excitement and delight. Was this part of your inspiration that made you consider it especially apt for Suji Kwock Kim's poetry?

Jérôme: Again, it was certainly not a conscious process but I would say that I do find it reflects my mindset regarding this work. And I am delighted if a parallel can be drawn between those two worlds.

Philipp: Besides percussion, practices of quotation have shaped contemporary music. You have mentioned that you were seeking sounds vaguely reminiscent of traditional Korean music, and also that you are wary of the current Canadian discourse on cultural appropriation. This raises a question at once political and aesthetic: Would you say that there is also a danger in contemporary musical composition of exoticism, and if yes, how would one forego the dangers and provide listeners with an experience that is revelatory while avoiding clichés? To me this seems a daunting task, especially in the face of gaps of cultural knowledge between (Far) East and West and different approaches in world and popular music.

Jérôme: I believe the dangers associated with exoticism and uses of clichés are greater than ever! In the post-colonial world we live in, we truly have a responsibility, as artists, to be extremely vigilant with this. I personally realize that this responsibility goes way beyond just aesthetic questions. Avoiding clichés is one thing .... I have always been annoyed by "postcard" music and have always tried to avoid it as much as I can. And up to a few years ago, I thought that if I could avoid those clichés and write something good, I "was OK." But I then realized that the problem with this can actually be much deeper. In some cases, writing something good or bad doesn't really matter. Taking a music out of its context, and whether you have the right to do it or not, is what really matters. Recently I came to realize that my euro-centric view of the world has me look at music in a purely aesthetic way. But for some people, music is much more than just beautiful sounds. It can be an integral part of their everyday life: it can be ritual; it can be sacred; it can heal. In some cases, it must remain private, even secret, and it should not be shared with anyone it is not intended to be shared with in the first place. Using such music in one's own work can be equivalent to profaning a tomb. Of course, this is a rather extreme example but for me it underlines the necessity to look at the broader picture when borrowing from another culture.

Philipp: Despite the rootedness of specific forms of music in specific cultures, rituals, and religions, one could think of music as being in exile once it is translated into another culture, such as by being appropriated by way of composition or improvisation. In this context, I always have to think of South and North Indian classical (Carnatic and Hindustani) music, which, since the twentieth century, has been carried so insouciantly into the Western world by 
its Indian exponents and offered for countless projects of fusion, adaptation, and appropriation by Western musicians and styles of music. This may seem astonishing from a Western perspective, given that this music is considered sacred and to belong to religious traditions and rituals. By comparison, some people in the Western world might take offence at a similar use of Western sacred music by composers such as Bach in a different musical idiom such as Indian classical music. While Indian classical music is premised on the idea that all music is already in the cosmos and humans are mere vessels actualizing it, in the West there is still the prevailing idea that compositional genius brings forth unprecedented sounds. Do you think that we would have to revise this attitude to arrive at a more relaxed perspective on cultural appropriation?

Jérôme: Those are excellent points and this question triggers in me numerous reflections. I will start by answering the very last part of your question. I don't know what it takes to arrive at a more relaxed perspective on cultural appropriation. I am no specialist on the matter, but what I gather is that it is a question of balance of powers between two groups of people. If one group has dominated the other for a certain period of time, then cultural borrowings by the dominator can be problematic and seen as theft. However, the other way around is not necessarily true. For example, some people argue that European or American rock bands from the 1960 s to 1970 s being heavily inspired by Mississippi Delta blues is cultural appropriation, but that African-American musicians using elements of tonal harmony, which is largely considered a European heritage, is not. In order to achieve a balanced cultural relationship between the two groups, I think we simply need to achieve a social balance. It is perhaps only when the wrongs of colonialism will have been corrected that a true balanced relationship will be possible, and that cultural appropriation will not be an issue anymore.

In that respect, I am, like you, somewhat surprised by how relaxed Indian musicians are with this question. You could think that after centuries of British domination, they would have a different attitude towards the West. With the sheer volume of Western music influenced by India since the beginning of the twentieth century, we have many examples of the best and the worst. Although many people in India must be annoyed by this, it does seem that still today the attitude is that if the borrowing is done with respect, and if it yields results that have artistic value, then it is accepted. But of course the question is, What is artistic value?

Regarding what one could call "reversed appropriation," for example "exporting" Western sacred music in an Indian music context, this is an excellent question, to which I do not have an answer. Some people may indeed take offence. I am not a religious person myself, so I am in no position to judge other people's reaction. For me, the only thing that really matters is whether the result is good or not. But again, what is good, what is not?

I find it interesting that you mention Bach in your question. If you don't mind, I would like to offer some further reflections here, that are perhaps not 100 per cent related to your question but that are triggered by it. Bach is by far my favourite composer. One must be cautious mentioning him while 
talking to me because it gets me "started." I feel that the music of Bach is simply indestructible, because it is so perfectly balanced and its beauty is so deep. Therefore, whatever is done to it, no matter how badly it is performed, arranged, or adapted, its beauty will always transpire; it will always survive. I could use myself as an example: my own instrument is the piano but I am a rather mediocre pianist. My favourite "classical" music to play is by far the music of Bach. I play it rather badly but it doesn't matter to me. Of course, I would never impose my poor skills on an audience. But for my own sake, despite my poor rendition of it, I am always capable of sensing the beauty and perfect balance of Bach's music when I play it. I cannot say the same of other corpora, such as Beethoven's sonatas: it just doesn't make sense trying to play them if you're not able to play them right.

So maybe this is why Indians don't mind their music being used by others, because they are so confident in its "solidity." But confidence in one's art forms cannot alone solve the problems of cultural appropriation. I do personally believe this whole question will only be solved by correcting the social imbalances that currently prevail between various groups of people.

Philipp: Extending and differentiating the range of quotational practices and the spectrum of quoted music from allusion to citation and recontextualization seems to be one of the main concerns in much of contemporary music. What has changed in this regard in contemporary music since the juxtapositional quotational practices in the music of George Crumb, for example, and those even more extreme historical and instrumental ones in the polystylistics of Alfred Schnittke?

Jérôme: Yes, the works of these composers have been tremendously influential. And it is true that those two examples you give present two very different approaches to borrowings. My own favourite example of quotational music is the third movement of Berio's Sinfonia ... which I see as foreshadowing sampling, in a pretty stunning way! Sampling, which is so important now, both in "serious" and "popular" music, is a good example of how boundaries between "high" and "low" art tend to disappear nowadays. And Schnittke's way of playing with styles and time periods is so postmodern, and the world we live in now is so very postmodern! I can certainly say that I relate to all of this myself 100 per cent-especially the postmodern aspect of things. My show mouvance is certainly a very good example of this. In fact, you will find many stylistic references in it, from Baroque and Renaissance music to today's rock and "folk" music.

And you ask what has changed since Crumb and Schnittke. Well, I am not a musicologist and don't pretend being able to offer a thorough analysis of today's contemporary music trends, but what strikes me with today's scene is how single aesthetic trends are becoming difficult to pin down. The keyword nowadays I believe is plurality. Of course, great composers of all times have always had their own individual voices, but the idea of plurality today is more far-reaching than ever, I believe. It touches every aspect of compositional practices and makes it more and more difficult to put the work of composers into 
categories, or stylistic "boxes." Crumb and Schnittke certainly have a great responsibility in this evolution.

Philipp: You have said that you decided to compose Fragments from a Broken Country because of your deep enthusiasm for Suji Kwock Kim's poetry cycle Notes from the Divided Country. Can you describe what made you so enthusiastic about her work?

Jérôme: I was just deeply moved by it! I found it utterly beautiful and moving. I was also particularly attracted by its modernity on the one hand, but also by its profound humanity on the other. The Korean war and the state of the Korean peninsula today is also a topic that is of great interest to me. I am particularly touched by all those families that have been separated by this war and by the fact that this still affects many families today.

Philipp: How did you choose the poems for Fragments from a Broken Country? How in general do you choose poems once you have discovered a poetic voice or cycle that particularly speaks to you?

Jérôme: When I set a text to music, I first read it several times, just to get a sense of it, overall. Especially when the text is quite long-that the whole text (in this case the whole book) is of interest to me, that I don't necessarily want to use just one poem, but that I can't obviously use the whole thing-I start looking for fragments that are especially meaningful to me. Then I start thinking of how I can extract those fragments and how I can recombine them in a new way. In that sense, this work on the text actually becomes an integral part of my musical thinking because the new structure I impose on those textual fragments will become the formal basis of my composition. This is also something I did with some of the Acadian texts I used in mouvance. Needless to say, I make sure the author is OK with this "butchery" ....

Then, once I have done this "macro-organization" work, I start looking at the details of each text and how I want to set them to music. My first step is to say the text out loud many times. Apparently, the great French writer Flaubert did this: I heard he had a room in his house he called his "gueuloir," where he literally shouted his texts. This very empirical, non-rigorous technique helps me "feel" the text-feel its natural rhythm, see where I want my setting to be more syllabic, or melismatic, or simply if I want to keep it spoken.

Keeping parts of the text spoken is something I do quite a bit, I must say, for a number of mostly practical reasons, I suppose. First, I will do this when the text is fairly long. Singing a text takes much more time than speaking it. If I like all the lines of a text and don't want to cut them, but I feel singing it all would become tedious both for the singer and the listener, I just have parts of it spoken. However, I must say my experience is that most singers don't like to go back and forth between singing and speaking a text. Apparently, it can be quite difficult to do .... I also very much like the natural flow and rhythm of the spoken text. Even when I do set a text to music, I very often do it very simply, in a way that is more syllabic than melismatic. I am also quite conservative in my prosody, usually just following the natural accentuation of the text, instead of trying some sophisticated prosodic "effects." 
One last note regarding the use of spoken words in my music: I think I tend to do it less nowadays. Earlier in my life, I was somehow intimidated by vocal music. I think I was trying to avoid writing purely melodic vocal parts perhaps just because I found it old-fashioned. Somehow I felt the need to be more experimental, daring, modern. So I would use the human voice more like an instrument, in the way of Berio's Sequenza III, for example, or I would just use the text itself, often "decomposing" it, a bit in the manner of Aperghis's Récitations. Another way for me of "dodging" melodic writing has been to actually use existing melodies, especially folk songs, like with my work Songs for Milena, for soprano and orchestra, inspired by the life and work of Czech journalist Milena Jesensnká. Nowadays, I enjoy writing purely melodic vocal music more and more. I suppose I embrace being old-fashioned, or cheesy ....

Philipp: In your comment on mouvance you spoke of the significance of exile, a topic also relevant to the war-related poems you chose for Fragments from a Broken Country. Can you explain the significance of exile for your music and its engagement with words?

Jérôme: It is true that the idea of exile is very important to me, almost an obsession ... especially since I moved to Halifax in 2004. I come from Quebec, a largely French-speaking (and anti-British) province in Canada, and Halifax, roughly a thousand kilometres from Montreal, is in Nova Scotia, an English-speaking province culturally very different from where I come from. This migration took place in the same country but for me it really felt a little bit like a form of exile. Of course, I am in no position to complain! My own exile is quite mild compared to that of so many others (and this is an understatement)! But this actually triggered many reflections in me and I became very interested in the subject matter. Several of my works can be seen as being influenced by this, at various levels, and in various degrees I suppose. The related topic of cultural and linguistic minorities is also of great interest to me. It is the case with mouvance, but also with Songs for Milena.

Philipp: Unlike Mayako Kubo's choral composition Hwajon (2007), which takes its title from one specific poem in the cycle, you chose to base the title of your composition on the title of Suji Kwock Kim's collection Notes from the Divided Country (2003) and one poem from this collection, "Fragments of the Forgotten War." What motivated this decision?

Jérôme: I think it is just because I was inspired by the whole work, not just one specific excerpt. I wrote this piece more than ten years ago, and I must confess I don't really recall the details of my thinking back then. And I also did not go back to my notes in order to do this interview .... So my overall recollection is simply that I juggled with various keywords that were related to the work and that were meaningful to me-a process, finally, that is not really different from what I did with the text of the poem itself.

Philipp: Can you comment on the choice and meaning of the title Fragments from a Broken Country? While on a surface level we may be thinking of Korea as a broken country, we can think of many other references for this part of the title. "Fragments" seem to refer both to music and to literature, as well as to bodies and souls fragmented by the atrocities of war. 
Jérôme: Yes, absolutely! I think the metaphor of human fragmentation is indeed a very good one. I did mention earlier how my work on the text is really based on the idea of fragmentation. Musical fragments is also certainly something many composers like to work with, and I am no exception. And as I said earlier, the fact that the Korean peninsula has been literally "fragmented" in two is something that I find particularly painful. So all of this must have influenced my decision to include the word fragments in my title. However, I don't recall this being a conscious decision.

Philipp: You may also have a more general understanding of the significance of titles in contemporary composition. While in a sense, many titles still follow Romantic precepts or break with them following the modernist tradition, I have a sense that composers now pursue individual approaches that reflect the diversity of contemporary music.

Jérôme: Ah, titles ... yes, a very interesting and important topic. I often have lengthy discussions about titles with my composition students. Many say they are not good with titles, that they don't like that they have to give titles to their pieces. "Why can't I just call this a 'Piece for Piano' or Sonata 1, like in the old days?," they say. I see what they mean. I was also like that when I was younger (much younger ...). But I tell them titles are much more important than you think; they are an integral part of your piece, and you should give your title as much creative attention as you give to the rest of your piece. In fact, I myself find very often that, when I still haven't found a title for a piece I am working on, it is symptomatic of a deeper problem. It often means that I am still not 100 per cent sure of what I want to do with this piece. Very often, the epiphany for the title of my piece will coincide with a "light bulb" moment for the piece itself! When I really know what I want to say with this piece, then I know what to call it.

\section{BIOGRAPHY}

Philipp Reisner is a lecturer at the American Studies Departments of Heinrich Heine University Düsseldorf and Johannes Gutenberg University Mainz. His doctoral dissertation on the New English theologian Cotton Mather (16631728) appeared in the Reformed Historical Theology series with Vandenhoeck \& Ruprecht in 2012. His multidisciplinary research focuses on early modern Anglo-America, religion in America, the histories of childhood, education, and music, and contemporary American poetry, drama, and short fiction. $\mathrm{He}$ is preparing a monograph on mysticism and religious motifs in contemporary American poetry. 